\title{
'Kattendyke', een goed verpakte surprise ${ }^{1}$
}

\section{Bunna Ebels-Hoving}

Eindelijk een succesverhaal in kroniekenland! Wanneer gebeurt het dat een editie van een middeleeuws handschrift binnen een jaar een tweede druk mag beleven? Maar vooral: wanneer komt het voor dat een interdisciplinair team erin slaagt om binnen enkele jaren een wetenschappelijk verantwoorde prachtuitgave te produceren? En dat nog wel van een onbekende kroniek, die tot nu toe geen rol in het historisch onderzoek heeft gespeeld? Zoiets is als gebeuren uitzonderlijk, en het resultaat is dat ook. De naam, Kattendyke-kroniek, is nieuw. ${ }^{2}$ Die dekt een fraai boek dat alles bevat wat historici zich wensen: editie, commentaren, en authentieke illustraties. Al bij een eerste doorbladeren vallen de vele fraai gekleurde banieren op, vaak vastgehouden door half uitgewiste, dus wat schemerige fabeldieren. Ligt hier soms een nieuwe gids voor het verkennen van de Noordnederlandse herfsttij? Dat studiegebied wordt al lang onderbedeeld wat betreft edities van verhalende bronnen, en is dus gebaat bij suggestieve nieuwe impulsen. Alleen al daarom verdient Kattendyke de aandacht.

Grondslag voor de relatief snelle realisering van de uitgave is de combinatie van drie uitzonderlijke omstandigheden. Allereerst is er de zeldzaamheid van een handgeschreven en rijkelijk verlucht boekwerk dat vier eeuwen lang door dezelfde familie wordt bewaard, en wel in zodanige staat dat de tand des tijds er wel wat aan geknabbeld, maar niet echt geknaagd heeft. Dat laatste is te danken aan de familie Huyssen van Kattendyke, bezitter van het handschrift sinds 1614. Want die is er waarachtig in geslaagd getrouwe uitvoering te geven aan de opdracht die koper-verzamelaar Johan Huyssen ooit zelf op het schutblad van zijn nieuwe aanwinst schreef: dat het manuscript steeds op de oudste zoon of diens plaatsvervanger moest vererven. Tweede gelukkig toeval is dat de schoonmoeder van de huidige baron, mevrouw Frank-van Westrienen, zelf historica, het boek zag, het belang ervan erkende en er een vakgenootkroniekdeskundige bijhaalde. En daarmee werd een derde gunstige draai aan het lot van het handschrift gegeven, want de deskundige, Karin Tilmans, ging tegelijk voortvarend en voorzichtig te werk: na enig eigen verkennend onderzoek $^{3}$ en jarenlang vruchtbaar gebruik van de kroniek in doctorale

1 Naar aanleiding van: A. Janse, e. a., ed., Johan Huyssen van Kattendyke-kroniek. Die historie of die cronicke van Hollant, van Zeelant ende van Vrieslant ende van den Stichte van Utrecht (Rijks Geschiedkundige Publicatiën, kleine serie CII; Den Haag: Instituut voor Nederlandse Geschiedenis, 2005, clxxvi + 630 blz., ISBN 905216140 2).

2 Voor het eerst gebruikt in de verkennende publicatie van K. Tilmans, 'De Kattendyke-kroniek. Een uniek kopijmanuscript uit Haarlem', in: J. M. M. Hermans, K. Verhoef, ed., Boeken in de late Middeleeuwen. Verslag van de Groninger Codicologendagen 1992 (Groningen, 1994) 183200.

3 Zie noot 2 en verdere publicaties in de bibliografie van de uitgegeven kroniek. 
beweging 'Der Sturm' in één adem genoemd met bekende kunstenaars als Klee, Kandinsky en Franz Marc. Tegenwoordig is Jacoba van Heemskerck geen naam van betekenis meer op de kunstmarkt, daar het grootste deel van haar werk in het bezit is van musea in binnen- en buitenland. In de jaren vijftig van de vorige eeuw werd in Nederland wel af en toe aandacht aan haar werk gegeven en in 1982 was er een interessante expositie van haar werk uit de expressionistische periode in het Gemeentehuis van Den Haag.

Het boek is opgebouwd uit twee delen, namelijk een monografie en een oeuvre-catalogus. Zowel de monografie als de oeuvre-catalogus zijn geschreven door kunsthistorica Jacqueline van Paaschen-Louwerse. Dit werk is een pionierstudie die voornamelijk gebaseerd is op bronnenmateriaal, ondanks het ontbreken van een persoonlijk archief. Het boek bevat mooie reproducties van het werk van Van Heemskerck, in kleur en zwart-wit, en verder alle beschikbare gegevens over haar werken en de collecties waarin deze zich bevinden, de herkomst ervan en de tentoonstellingen waar ze hebben gehangen; kortom een fantastisch boek waarin de persoon en het werk van de kunstenares Jacoba van Heemskerck volledig tot leven worden gebracht en de lezer dieper inzicht krijgt in zowel haar drijfveren als haar manier van werken. Tevens is het een uitstekend naslagwerk voor allen die geïnteresseerd zijn in de avant-garde kunst van deze periode.

Gwendolyn E. van Essen 
Wat staat erin? Allereerst, gelukkig, een integrale teksteditie. Dat lijkt vanzelfsprekend maar is dat geenszins. Als we onszelf toestaan de wetenschapspolitiek correcte bril even af te zetten zien we een kroniek die niet alleen lang is maar ook opvallend veel (en juist heel veel bekende) fantasterij bevat. Zo is direct te zien dat de Trojaanse voorgeschiedenis van Holland hier behoorlijk uit de schrijvershand is gelopen. Een negentiende-eeuwse redactie zou dat hele stuk geschrapt hebben. Maar de tekstbezorger Antheun Janse, die zo eerlijk is zich het nut van een integrale editie van juist deze Kattendyke af te vragen, komt ook meteen met het momenteel enig juiste antwoord: 'de Kattendyke-kroniek geeft ons een indruk van de kennis die een geïnteresseerde leek vlak voor het jaar 1500 had van zijn eigen geschiedenis ... welke teksten hij tot zijn beschikking had, en welke thema's hij belangrijk vond.' ${ }^{6}$ Dat zijn de dingen die we tegenwoordig onderzoeken en daarvoor hebben we het hele werk nodig in de vorm waarin het ooit werd geconcipieerd. Een op 'historische nonsens' gekuiste Kattendyke zou voor het huidige onderzoek geen waarde gehad hebben. Janse heeft gelijk als hij stelt dat de laatmiddeleeuwse Noordnederlandse geschiedschrijving in de laatste halve eeuw wel redelijk intensief bestudeerd is, maar steeds zonder de controleerbare basis van goede tekstedities. We mogen hem dus dankbaar zijn omdat hij het werk op zich nam en het met grote acribie uitvoerde, daarin geholpen door Ingrid Biesheuvel (en eerdere transcripties die al door studenten van Karin Tilmans waren gemaakt).

Ik heb maar een enkele opmerking. Òf Janse zelf als tekstbezorger, of misschien de hele redactie heeft gekozen voor een beperking tot puur formeeltekstuele annotatie. Dit betekent dat het hele commentaar zich bepaalt tot de obligate vermeldingen van doorhalingen, verschrijvingen en vergissingen in de oorspronkelijke tekst. $\mathrm{Er}$ is dus helemaal afgezien van inhoudelijke uitleg. Begrijpelijk is dat zeker, want informeren over het wie/wat/waar kost tijd en moeite. ${ }^{7}$ Als troost voor de lezer verwijst Janse naar de index, waarin men bijvoorbeeld regeringsjaren kan vinden. Maar daarbij blijft het dan ook. Voor andere vragen geldt het kluitje in het riet. ${ }^{8}$ Het lijkt me dat het beoogde lezerspubliek van juist deze kroniek, ook het professionele, nu wel veel noodzakelijke verklaring mist. Ook op het gebied van het Middelnederlands! Laten we, ook als vaklieden onderling, niet doen alsof dat geen problemen kan opleveren. Kattendyke laat zich goed lezen, maar juist daarom zou een enkele

6 A. Janse, 'De tekst van de Kattendyke-kroniek' (Tekst uitgesproken bij de presentatie op 23 mei 2005; Den Haag, 2005) ongepagineerd.

7 Maar het kan wel, zoals blijkt in de drie in de vorige noten genoemde edities. De uitgevers van Peter van Os kozen voor een 'terughoudende tekstkritische en historische annotatie'; Bruch geeft voornamelijk tekstvarianten maar voorziet die soms van ander commentaar; en Burgers handelt ideaal, namelijk met drie categorieën: tekstcommentaar, woordverklaringen en zaak-uitleg.

8 Komisch voorbeeld, direct an het begin (stichting-van-Troje-verhaal, 7): er is sprake van ene Bocasius die aan Jupiters zoon Dardanus een bepaalde afkomst geeft 'int seste boeck van den genealogie vanden goden.' De argeloze lezer denkt 'kan dit Boccaccio zijn? Die heeft toch een de genealogiis deorum?', kijkt in de index, en vindt daar: 'Bocasius, schrijver'. (!) 
handreiking geholpen hebben om het uitgesproken doel van de tekstbezorger, het bieden van 'een toegankelijke en bruikbare leestekst', te verwezenlijken.'

Vermoedelijk zijn redactie en uitgever al werkende aan hun Kattendyke de kroniek toch vooral als een studietekst gaan zien, die zijn oorspronkelijk doel: lering en vermaak heeft ingeruild voor een 'zuiver wetenschappelijk': de tekst als noodzakelijke substraat voor materiële en inhoudelijke analyse van de pasontdekte kroniek. En een eerste grondige analyse wordt meteen bijgeleverd, in de vorm van liefst zes deelstudies die dan ook nog eens door de eindredactrice worden samengevat. Kattendyke is in een eigentijdse en buitengewoon goed verzorgde wieg gelegd. Als inleiders zijn experts aangetrokken, en al in de eerste twee studies blijkt dat voor iets extra's te zorgen: een uitgewerkt profiel van de eerste bekende bezitter van het handschrift. Ridder Johan Huyssen van Kattendyke verwierf het toen al meer dan een eeuw oude manuscript in 1614, en voorzag het eigenhandig van aantekeningen op de schutbladen. Corrie Ridderikhoff is erin geslaagd deze haast onleesbare bron te ontcijferen. Daarnaast heeft kunsthistoricus Rudi Ekkart liefst vijf portretten van hem kunnen traceren, te weten een levensgroot schilderij, twee verschillende gravures, een tekening, en een ingegraveerde zilveren plaquette. Mooi is dat dit schriftelijke en materiële bronmateriaal elkaar versterkt in de constructie van één beeld: dat van een zeer respectabel en ook zeer zelfbewust man. Iemand van groot maatschappelijk gewicht, onder meer lid van de Staten van Zeeland, en in de loop van zijn carrière geridderd door zowel de Franse als de Engelse koning. En ook een erudiet: hij laat zich portretteren met boek in de hand. De kroniek die later zijn naam zou dragen had hij echter niet op grond van studieuze, maar van persoonlijke interesse gekocht. Hij moet namelijk geweten hebben dat het handschrift ooit in bezit was geweest van zijn moeders familie, de uit Brugge afkomstige Hannemans, die zich rond 1500 in Den Haag gevestigd hadden. Zijn krabbels op de schutbladen zijn van genealogische aard en maken het mogelijk de families Huyssen en Hanneman te reconstrueren, en daarmee het gat in de bezittersgeschiedenis van het al in 1491 ontstane manuscript ${ }^{10}$ te verkleinen. Aan tekstkritische aantekeningen waagde de nieuwe bezitter zich echter niet. Dus zien we ook wat ridder Huyssen niet was: hij was geen Dousa, Scriverius, Sweertius of Buchelius, geleerden die zich juist in zijn tijd met Hollands oudste verleden bezighielden. ${ }^{11}$ Hij liet zijn boek geen rol in dat circuit spelen. De enige geleerde die het een tijdlang gezien heeft en er een enkele aantekening in maakte was de officiële geschiedschrijver van

9 Voorbeelden op zomaar wat bladzijden: al syn bloet veranderde hem $=$ hij verbleekte (7); ontsich $=$ vrees $(47) ;$ missaken $=$ ontkennen, missing = mest $(62)$; ghesceit $=$ kruispunt $(82) ;$ sy toghen weder overstier $=$ ze gingen weg (98); ontleet $=$ in stukken gescheurd (210); bestorven kint $=$ erfdochter (229).

10 Alle auteurs zijn het eens over deze datering, die zowel door het gebruikte papier als door een inhoudelijke opmerking wordt gestaafd, al in de eerste publicatie over Kattendyke (zie noot 2) is geopperd en nu wordt bevestigd in de editie, cxlv.

11 Ridderikhoff en Ekkart maken deze afweging niet, maar zie S. Langereis, Geschiedenis als ambacht. Oudheidkunde in de Gouden Eeuw. Arnoldus Buchelius en Petrus Scriverius (Hilversum, 2001) (Niet vermeld in de bibliografie van Kattendyke.) 
Holland, Pieter Bockenberg ( $†$ 1617), maar juist hij heeft noch in eigen tijd, noch later het respect van vakgenoten verworven. ${ }^{12}$ Het boek bleef dus niet alleen van maar ook binnen de familie, en miste zo de kans om gedrukt te worden, wat juist in deze jaren wèl met een aantal andere laatmiddeleeuwse kronieken gebeurde. ${ }^{13}$ Dus werd het niet becommentarieerd, maar daar staat tegenover dat het ontsnapte aan het bekende gevaar van na de druk weggegooid te worden. Het lot van het manuscript lag besloten in de aard van zijn bezitter.

$\mathrm{Nu}$ het na vier eeuwen toch nog publiek bezit is geworden kunnen we het onderzoeken op zijn ontstaan en oorspronkelijke bedoeling. Twee volgende experts, Jos Biemans en Wim van Anrooij, hebben de kroniek ontleed op zijn uiterlijke verschijningsvorm, respectievelijk als codicoloog en als kenner van heraldische afbeeldingen. Samen hebben zij ervoor gezorgd dat het manuscript als 'handwerk' veel aandacht krijgt, aanzienlijk meer dan het boek als intellectueel concept (53 tegenover 31 pagina's). Dit roept natuurlijk direct de vraag op of de Kattendyke-kroniek als object, als resultaat van planmatig ontwerp, misschien belangrijker is dan als 'stuk geschiedschrijving'. Van Anrooij en Biemans zorgen ervoor dat we dit manuscript als een totaalproject kunnen zien. De eerste doet dat vooral door nadruk op het illustratieve knipen plakwerk, en de tweede ondersteunt die met een nauwgezette analyse van de katern-opbouw en de hier en daar noodzakelijke invoeging van losse bladen. Het letterlijke mooie van het manuscript bestaat uit verluchting met ingeschilderde heraldische wapens en met ingeplakte, van elders uitgesneden of verkregen houtsneden. Die illustraties zijn verre van lukraak aangebracht: ze horen bij de tekst en gedurende het schrijfproces is al rekening met hun invoeging gehouden. Dat procédé leidt de auteurs tot de niet onbelangrijke conclusie dat hier één maker aan het werk is geweest, althans één man die van tevoren een beeld had van 'wat de kroniek ging worden', en die de regie over het geheel hield, al liet hij het fijnere schilderwerk misschien aan een ander over. $^{14}$

Aan die conclusie valt niet te tornen, maar omdat er erg veel nadruk op wordt gelegd, en bij herhaling, mag er misschien een kanttekening bij worden gemaakt. Een verzamelhandschrift is Kattendyke duidelijk niet, dat is bijna op slag te zien, en ook maakt het als geheel daarvan geen deel uit. Wat kan het

12 Zie K. Tilmans, 'De Trojaanse mythe voorbij. Of: Waarom de Kattendyke-kroniek alleen door Bockenberg opgemerkt werd', It Beaken, LVI (1994) 190-191. Tilmans meent hier nog dat het Bockenberg was die de kroniek aan Leydis toeschreef (zie hierna 9-10), maar Corrie Ridderikhoff heeft die veronderstelling door haar handschriftelijk onderzoek ontkracht, Kattendyke, xxxvi.

13 Vgl. B. Ebels-Hoving, 'Nederlandse geschiedschrijving 1350-1530. Een poging tot karakterisering', in: idem, C. G. Santing, C. P. H. M. Tilmans, ed., Genoechlicke ende lustige historiën. Laatmiddeleeuwse geschiedschrijving in Nederland (Hilversum, 1987) 239-240.

14 Kenmerkend voor de voorzichtigheid van de drie samen-schrijvende auteurs Van Anrooij, Biemans en Janse is dat ze enerzijds de mogelijkheid noteren dat het bij de auteur 'om een vrouw kan gaan', maar daar dan in een noot aan toevoegen dat 'dat gezien de opzet en de overlevering niet erg waarschijnlijk is', cxl (wat ik met ze eens ben). 
dan goedbeschouwd anders zijn dan een eenmanswerk? De maker van dit boek verkeerde duidelijk niet in een hof-situatie waar het aanzoeken van gespecialiseerde miniaturisten van elders voor kon komen. En omdat hij schreef, niet drukte, ontkwam hij aan het gevaar van slechte correlatie van tekst en illustratie. De Kattendyke-auteur is blijkens zijn werk een eenling, een makersamensteller geweest, goed vergelijkbaar met de student-van-nu, die zijn werkstuk al knippend en plakkend uit voorhanden tekst- en beeldmateriaal samenstelt. Het aardige is dat de Kattendyke-man illustreert hoe de beroemde overgang van 'script to print', die juist in de tijd van de vervaardiging van onze kroniek volop aan de gang was, verliep. Dat we hier te maken hebben met een geschreven tekst die gedeeltelijk met gedrukt materiaal is versierd geeft aan dat drukken en schrijven in verschillende vorm naast elkaar bleven bestaan. Dit moet ons ervoor behoeden dat we in Kattendyke iets zien dat in zijn tijd van ontstaan, eind vijftiende eeuw, 'ouderwets' was; het gesleutel aan de precieze inpassing van tekst en beeld dat Van Anrooij ons zo mooi laat zien heeft eerder iets nieuws en loopt direct uit op de samenwerking die al toen, maar ook lang daarna, plaatsvond in de drukkerswerkplaatsen. Misschien zat er soms wel eens een behulpzame plakker of inkleurder naast de schrijver van onze kroniek, maar het zou onrealistisch zijn om te denken dat het werk werd uitgedeeld.

Boekgeschiedenis is interessant, maar wat we als historici vooral willen weten is wie daar nu zat te schrijven, hoe en waar hij werkte, met welke inhoud en voor wie? Antwoord op die vragen zoeken Antheun Janse ('De Kattendyke-kroniek als historiografische bron'), en Janse, Van Anrooij en Biemans tezamen ('Karakteristiek van de auteur'). Wat zij aandragen wordt dan nog eens door Karin Tilmans samengevat ('De Johan Huyssen van Kattendyke-kroniek. Geschiedenis en belang van de uitgave'). En dan blijkt dat de lezer van de afzonderlijke inleidingen het wel eens moeilijk kan krijgen, want anders dan bij de twee al besproken opstellen die elkaars gegevens versterken, is er nu ook wel eens sprake van verschillende accenten die tot tegenspraak kunnen leiden, of juist tot een soort neutralisatie van standpunten. Ik probeer de resultaten bijeen te brengen aan de hand van vier punten: 1 . het beoogde publiek, 2. de inhoud, 3. de plaats van vervaardiging, en 4 . de auteur.

Ten eerste: voor wie kan dit boek zijn bedoeld? Omdat een auteur zich meestal in zijn proloog tot een beoogd publiek wendt zoekt Janse terecht allereerst dáár. ${ }^{15}$ Een beetje jammer is dat dan blijkt dat de (vooralsnog onbekende) Kattendyke-schrijver zijn proloog overneemt van een van zijn belangrijkste bronnen, de in 1480 gedrukte Fasciculus temporum van Johan Veldener. Maar hij voegt daar zelf iets aan toe door zich aan het eind te richten tot 'veel menschen die die historie of cronicke van Hollant ende van Utrecht begheren te lesen' en juist voor hen zijn inhoud samen te vatten. ${ }^{16}$ Hij zoekt

15 Vgl. Y. G. Vermeulen, Tot profijt en genoegen. Motiveringen voor de produktie van Nederlandstalige gedrukte teksten 1477-1540 (Groningen, 1986) 57-65 (over de prologen in handschriften). (Niet vermeld in de bibliografie van Kattendyke.)

16 Kattendyke, 3-4. Die inhoud: 'so willen wij eerst beginnen van den oerspronc ende beghinsel waer dat Hollant ende Utrecht ende Vrieslant ende alle dese Nederlanden uut den bloede van 
dus een breed publiek. Maar Janse gelooft niet dat hij in dit opzicht oprecht is. Hij denkt dat de schrijver Veldeners proloog als het ware automatisch overnam, maar in werkelijkheid een andere intentie had. Hij schreef namelijk geen tekst die 'gepubliceerd' en verspreid moest worden, maar vervaardigde een mooi handschrift dat nu juist bedoeld was om 'door liefhebbers ... gebruikt en bewonderd te worden ${ }^{17}$; hij dacht dus eerder aan een adellijke of althans hooggeplaatste koper. Karin Tilmans blijkt het op dit punt met Janse niet eens te zijn; zij gelooft de auteur op zijn woord en houdt het er dus op dat hij op veel lezers mikte. Maar zij erkent dat dit mikken geen doel heeft getroffen, want de kroniek bleef ongedrukt en dus (waarschijnlijk) ongelezen liggen. Mogelijke oorzaak daarvan was wellicht een verkeerd inschatten van de aard van de publieke belangstelling door de auteur: híj dacht dat de tijd rijp was voor een mooi product van serieuze geschiedschrijving, maar die 'vele menschen' die hij op het oog had wilden iets anders. ${ }^{18}$ Ik denk dat er wel een oplossing is voor deze kleine controverse. Het ligt voor de hand om de auteur op zijn woord te geloven, want niets gebood hem om aan de proloog van Veldener zijn eigen 'doelgroep' toe te voegen, en dus zal hij wel degelijk een ruim publiek van geïnteresseerden voor ogen hebben gehad. Maar ... geen drukker uit zijn omgeving kon zijn mooie gekleurde plaatjes aan! De verwezenlijking van het idee van onze auteur: het aanbieden van een aangepaste, bijgewerkte én in kleur geillustreerde Veldener bleek heel gewoon te duur. ${ }^{19}$ Dat was jammer voor zijn geïntendeerde publiek, dat bestond uit regenten die wel graag ridders wilden worden. ${ }^{20}$

Tweede punt: met welke inhoud wilde hij die bovenlaag dan stichten, informeren en boeien? Ook dat maakt hij in zijn proloog duidelijk: met een stichtelijk verhaal vanaf de Schepping tot $n u$, dat uitloopt op de geschiedenis van Holland en Utrecht. Met dat voornemen voegt hij zich geheel in de eisen van zijn tijd, want de heersende vorm van geschiedschrijving was die van de 'toegespitste wereldkroniek. ${ }^{21}$ Dat was een zwaar, veeleisend concept. Veeleisend vooral omdat die ambitie om van $\mathrm{A}$ tot $\mathrm{Z}$ te gaan in de loop van de vijftiende eeuw een heel bepaald en eigenaardig accent krijgt: het begin, de eigen origo, krijgt steeds meer aandacht en plaats, en dat gaat ten koste van de behandeling van de jongste geschiedenis. Een feit is dat veel manuscripten

Troyen ghesproten is ... Ende voert van allen heeren die dese landen begrepen hebben ... ende specialicken van Hollant ende van Uutrecht. Ende hoe dat den eersten graef Dirc het lant ghegheven wort tot den coninc Maximiliaen. Ende van allen heeren ende bisscoppen van Uutrecht tot biscop David toe... .'

17 Kattendyke, clii-cliii.

18 Ibidem, xviii.

19 Over de zakelijke risico's van de eerste generatie drukkers is veel geschreven; zie speciaal voor Haarlem W. Keesman, 'Jacob Bellaert en Haarlem', in: E. K. Grootes, ed., Haarlems Helicon. Literatuur en toneel te Haarlem vóór 1800 (Hilversum, 1993) 27-48, hier 47.

20 De omgekeerde weg dus van die van Van Nierop: H. F. K. van Nierop, Van ridders tot regenten. De Hollandse adel in de zestiende en de eerste helft van de zeventiende eeuw (Dieren, 1984).

21 Zie Ebels-Hoving, 'Nederlandse geschiedschrijving 1350-1530', 227-229. 
afbreken voordat de eigen tijd is bereikt. Nu ligt de oorsprong van Holland in Troje, dat weet men rond 1490 al eeuwenlang, en op dat punt denken de chroniqueurs vanaf ongeveer 1450 nog steeds meer kennis te kunnen etaleren. Onze auteur weet alweer meer dan zijn directe voorgangers als Johannes a Leydis of Willem van Berchem. Hij kon profiteren van twee recentelijk (1485) in Haarlem gedrukte bronnen, 'romans. ${ }^{, 22}$ Voor het gevoel van de huidige lezer komt hij echter pas op vastere historische grond te staan als hij op inheemse verhalende bronnen kan steunen; en gelukkig, dit deel van zijn werk beslaat, naar Janse heeft berekend, $80 \%$ van de inhoud, met daarbinnen nog weer veel nadruk op de jaren 1370-1430 (meer dan een kwart van het totale werk gaat over déze 60 jaar). En dan loopt het nog door tot 1478 .

Maar laat nu niemand denken dat er in deze pas ontdekte kroniek iets nieuws staat. Heel globaal gezegd is Kattendyke een mengsel van Veldener met Vermeerderde Beke, plus nog twee of drie handschriften met vooral 'Hollands' materiaal. Janse heeft die bronnen niet alleen nauwgezet getraceerd, maar geeft ze ook op een bescheiden, handige manier in de kantlijn aan (geen gezoek in de voetnoten dus). Ik heb bewondering voor het gedane onderzoek, maar durf er toch drie opmerkingen over te maken, omdat die consequenties hebben voor het begrip van de tekst als geheel, en ook voor de zoektocht naar de auteur. De eerste betreft Janse's inschatting van de bedoelingen van de Kattendykeauteur. Terecht gaat hij uitvoerig in op diens compilatietechniek, die uit meer of minder handig knip-, plak- en vlechtwerk bestaat. Maar, vraagt Janse zich af: doet onze auteur dan nooit iets méér, brengt hij nergens iets van zichzelf in? Bijvoorbeeld door het leggen van extra nadruk op zijn brontekst, of juist door er stukken uit weg te laten? Of heel misschien toch door er een zelfbedacht stukje tekst aan toe te voegen? Het valt te prijzen dat Janse die laatste mogelijkheid openlaat door een enkele onherleidbare passage open en uitvoerig te bespreken. ${ }^{23}$ En zijn conclusie, tenslotte, dat de schrijver nooit zelfstandig terugblikt of evalueert, dus geen enkel blijk geeft van distantie tegenover zijn bronnen, is in het licht van zijn eigen Kattendyke-onderzoek volkomen terecht. Alleen: dit resultaat krijgt veel nadruk, en daarmee dreigt Janse zijn auteur buiten zijn tijd en plaats te trekken; diens opzet was geen andere dan die van zijn collega's in binnen- en buitenland, namelijk het gebruik van bronnen die hijzelf als authentiek en goedgekeurd beschouwde ${ }^{24}-$ en van

22 Namelijk Die vergaderinge der historien van Trojen, en: Historie van den vromen ridder Jason, twee vertalingen uit het Frans die de Haarlemse drukker Jacob Bellaert 1484-1485 had uitgegeven, Kattendyke, cxxv, waar verwezen wordt naar de ontdekking van deze bronnen door Karin Tilmans, zie noot 2.

23 De moeilijkheid is hier dat toevoegingen als 'als ic heb horen segghen' ook uit de brontekst kunnen komen, zoals Janse zelf erkent, Kattendyke, cxxxi. De drie 'onherleidbare' passages, cxxix-cxxx, komen denk ik wel voor in de Latijnse geschiedschrijving, met name in Pauli (Utrecht UB hs 1650) en 'Leydis I' (Leiden UB BPL 127d) of het Magnum Chronicon Belgicum, ed. J. Pistorius, 1606. Zie voor het mogelijk gebruik van Latijnse kronieken door onze auteur hierna.

24 Nog steeds onverbeterd beschreven door B. Guenée, 'Authentique et approuvé'. Recherches sur les principes de la critique historique au Moyen Age', Actes du colloque international sur 
niets anders. Maar die bronnen moesten dan ook nog beschikbaar zijn, dat wil zeggen: aanwezig op zijn werkplek. ${ }^{25}$ De expliciete vraag dus: 'heeft de auteur zijn bronnen bewust uitgekozen ${ }^{26}$ neigt naar onbegrip van de situatie van de laatmiddeleeuwse chroniqueur die zat waar zijn materiaal lag. Zelf ging hij zelden of nooit op zoek. Dus is het van belang wáár de Kattendyke-man zat te schrijven en plaatjes te knippen en kleuren, maar daarover straks. Eerst nog de twee andere opmerkingen bij Janse's brononderzoek. Voor het laatste deel van de kroniek heeft hij naast de gedrukte Veldener nog twee handschriften getraceerd, één van het later zo genoemde Goudse kroniekje, en één dat hijzelf de werktitel Haagse kroniek geeft. ${ }^{27}$ Het is duidelijk dat er in deze twee bronnen veel materiaal zit dat Kattendyke óók heeft. Maar de gewekte idee dat ze de directe bron vormen is om twee redenen gevaarlijk. Ten eerste moeten we ons steeds blijven realiseren dat het volkomen toevallig is wat we nog aan laatmiddeleeuws kroniekmateriaal over hebben: we zoeken braaf in de resten en moeten dat zeker doen, maar toch met een zekere losheid tegenover de mogelijkheid om dé bron te vinden. Het tweede is veel belangrijker: we moeten voor een Middelnederlandse bron absoluut ook in de Latijnse kijken! ${ }^{28}$ Ik denk dat dit niet of vluchtig is gebeurd omdat de auteurs haast bij voorbaat hebben aangenomen dat een gebrekkige grammaticale kennis van het Latijn een passief gebruik van teksten verhinderde. ${ }^{29} \mathrm{Op}$ deze kwestie komen we nog terug. ${ }^{30}$

We hebben nu een publiek en een werkwijze, maar nog geen plaats, en ook geen auteur. De ene identificatie kan naar de andere leiden. Voor de plaats leek Haarlem direct een sterke kandidaat, zoals Karin Tilmans in haar voorpublicaties over Kattendyke al aantoonde. Haar argumenten vormden onder meer het 'Haarlemse penwerk', het gebruik van twee in de voorgaande jaren in Haarlem gedrukte bronnen voor de Troje-stof, ${ }^{31}$ en het waarschijnlijke benutten van een

la lexicographie du latin médiéval (Parijs, 1978), of: Idem, Histoire et culture historique dans l'Occident médiéval (Parijs, 1980) 129-147.

25 Zie F.-J. Schmale, Funktion und Formen mittelalterlicher Geschichtsschreibung. Eine Einführung (Darmstadt, 1985) 86 e. v.

26 Janse, Kattendyke, cxxxvi.

27 Het is het ms. Den Haag KB 130 C 10, bevattende de Nederlandse Beke tot 1425 met anonieme vervolgen tot 1478 (waar Kattendyke ophoudt.) Het is duidelijk dat dit handschrift een belangrijke bron voor het laatste deel Kattendyke is, maar ik vind de betiteling Haagse kroniek niet gelukkig: er komt wel een enkele 'Haagse' (kerkelijke) vermelding in voor, maar de algemene nadruk lijkt me eerder te liggen op Bourgondië en Brederode.

28 Is die lange, volgens Janse onherleidbare passage over Jacoba van Beieren niet gewoon uit Pauli's Hystoria? (M. Carasso-Kok, Repertorium van verhalende historische bronnen wit de Middeleeuwen ('s-Gravenhage, 1981) no. 220).

29 Op dit punt heeft Karin Tilmans de toon gezet, al vanaf haar eerste Kattendyke-publicatie, noot 2. Herhaaldelijk valt het woord 'ontoegankelijk' voor de Latijnse bronnen.

30 Toen Bruch zijn Nederlandse Beke uitgaf (1982) zocht hij zijn bronnen voor de Vermeerderingen nog in zowel Middelnederlands als Latijns materiaal. Het is jammer dat deze vanzelfsprekendheid verloren is gegaan.

31 Zie hiervoor noot 22. 
handschrift uit de omgeving van de Haarlemse kanselarij. ${ }^{32}$ Daarbij kwam het intrigerende feit dat iemand, een onbekende uit de omgeving van Johan Huyssen van Kattendyke, onderaan de kroniektekst de naam Joannis gerbrandus aantekende, en dat is de Haarlemse karmeliet en chroniqueur Johannes a Leydis. Op hem komen we terug, maar hier gaat het alleen om de plaats. Het valt op dat de drie auteurs Janse, Van Anrooij en Biemans veel moeite doen om hun kroniekschrijver van Haarlem los te maken en daartoe onder meer diep ingaan op de eerder door Tilmans veronderstelde Brederodeconnectie (Santpoort), die inderdaad niet sterk is. ${ }^{33}$ Maar er zijn andere argumenten die de onbevangen lezer toch wel sterk in Haarlemse richting duwen. Daarvoor moeten we proberen ons de situatie van de Kattendyke-man voor te stellen. Hij moet in het scriptorium van een klooster of heel misschien in de librije van een kerk hebben gewerkt, want voor een stads- dan wel adellijke privé-bibliotheek is het in Holland omstreeks 1490 nog te vroeg. Welnu, in het scriptorium van het Haarlemse Karmelietenklooster werkte juist in deze jaren de zojuist genoemde prior (of sub-prior) Johannes a Leydis, die zijn in het Latijn geschreven Hollandse kroniek had herzien en nu bezig was met een Nederlandse en een Latijnse Brederode-kroniek. Ook werkte hij precies in het jaar 1491, waarin de auteurs het ontstaan van Kattendyke dateren, aan het afschrift van een wereldkroniek (geschreven door de Gentse karmeliet Arnoldus Bostius ${ }^{34}$ ). Voor dat alles moeten de bronnen ergens om hem heen gestaan hebben, en zijn plaats was het Karmelietenklooster. Het is niet onwaarschijnlijk dat zich daar ook de in Haarlem gedrukte Troje-boeken bevonden, en misschien ook wel het al vermelde Haarlemse handschrift met afschriften van liefst zeven kronieken, zowel van wereld- als van regionaalhistorische aard. ${ }^{35}$ Een op z'n minst handige werkplek, ook voor onze auteur. En zo stimulerend, want juist in diezelfde jaren 1490 werden in de kloostergang de Hollandse gravenportretten opgehangen, ${ }^{36}$ die een zichtbaar stramien boden waarop Leydis, maar ook de Kattendyke-auteur, een belangrijk deel van hun verhaal bouwden.

Maar wie wàs die schrijver dan? We kennen zijn naam niet, maar over zijn profiel zijn alle inleiders, de drie zojuist genoemde én eindredactrice Karin Tilmans, het hartgrondig eens: hij was een leek, kende niet of nauwelijks Latijn, hij was niet van het niveau van een Leydis of een Aurelius, hij hoorde

$32 \mathrm{Nu}$ ms. Leiden UB, BPL 76c.

33 Op dat punt hebben de drie auteurs gelijk: de Brederode-aandacht, zowel heraldisch als tekstueel, was in de late vijftiende eeuw 'algemeen-Hollands', Kattendyke, cxlvi-cxlvii.

34 Een vroege humanist, zie J. IJsewijn, 'The coming of humanism to the Low Countries', Itinerarium Italicum. The Profile of the Italian Renaissance in the Mirror of its European transformations, H. A. Oberman, T. A. Brady, ed. (Leiden, 1975) 193-301, hier 201, 224, 274275.

35 Zie noot 32. Bij Carasso-Kok, Repertorium van verhalende historische bronnen, staat de inhoud van dit ms. onder de separate nummers 139, 181, 186, 188, 193, 200 en 340.

36 Dat ze dáár hingen, en niet al direct, zoals nu, in het stadhuis, werd mij pas duidelijk door W. van Anrooij, ed., De Haarlemse gravenportretten. Hollandse geschiedenis in woord en beeld. (Hilversum, 1997). 
dus niet tot de 'intelligentsia van het graafschap Holland', hij hoorde zelfs niet tot het milieu van de schrijvende ambtenarij. ${ }^{37}$ Eigenlijk heeft hij maar één verdienste: hij kende en gebruikte zijn bronnen, toegewijd en ijverig. Ook in zekere zin wel methodisch, maar dat maakt hem nog niet tot een 'professional', integendeel, zijn niveau is dat van de 'gedreven amateur.' Al met al, is de unanieme conclusie, blijft zijn profiel onscherp. ${ }^{38}$

Ik denk dat het scherper kan worden als we onze lens wat draaien. Allereerst zal blijken dat de gebruikte kwalificaties vervagend werken omdat ze niet in de tijd passen. Alle inleiders vinden de kroniek een unieke prestatie. Wat betekenen in dit licht dan die steeds herhaalde termen 'amateur' en 'professional'? Iedereen weet dat de professionele historicus een schepping van de negentiende eeuw is, dus wat wordt hier dan bedoeld: een Latinist (dus een geestelijke?), een drukker (dus een leek?), een ervaren boekverluchter (kan allebei?). Het is inderdaad duidelijk dat onze man dat alles niet is, maar wel kan hij lezen, schrijven en combineren, en vervaardigt een substantieel en origineel product. Wat betekent het dat zo iemand niet tot de 'intelligentsia' behoort? Ik denk dat de inleiders zich op glad ijs begeven, begripshistorisch gezien, maar hun reden is duidelijk: onze auteur dankt zijn 'low profile' vooral aan zijn slordige omgang met het Latijn. De grammatica beheerst hij niet, en hij schrijft puer op als puwer! Dat betekent dat de Latijnse bronnen voor hem 'ontoegankelijk' waren, en dus had hij maar gebrekkig deel aan de cultuur van zijn tijd. Maar dan blijkt toch ineens dat hij een Latijnse passage die hij in een Nederlands Beke-vervolg aantrof wél kan vertalen. ${ }^{39}$ En dat hij zijn proloog begint met een Latijnse psalmtekst, die hij weliswaar van Veldener overneemt, maar blijkbaar niet als een barrière voor zijn lezers voelt. Kennelijk moeten we hier niet in de uitersten van 'Latinisten' of 'volkstaligen' denken. Precies dat is nog onlangs benadrukt in het werk van P. Wackers en van Saskia Bogaart: de laatste spreekt van het bestaan, zo rond 1500, van een 'tweetalig publiek ... ontwikkelde personen die (een beetje) kennis hebben van het Latijn en die zich weliswaar ... buiten de hogere wetenschappelijke milieus bevinden, maar zich desondanks minstens op de grenzen van de Latinitas begeven. ${ }^{40}$ Juist in de late vijftiende eeuw is er (ook) in de Nederlanden sprake van verwevenheid van de Latijnse en de volkstalige cultuur, een situatie die nu bestaat in Nederlandse omgang met het Engels.

Dus opnieuw, en nu zonder vooringenomenheid: wie wás de auteur? Ooit heeft er op dit punt zekerheid bestaan. Toen ridder Johan Huyssen van Kattendyke zijn boek in 1614 verwierf liet hij het, zo veronderstelt Corrie Ridderikhoff, trots aan sommige bezoekers zien, en één van die bevoorrechten schreef 'met een grove pen' onderaan het laatste blad: Johannis gerbrandus auctore. Raar Latijn, maar ook als geheel een raar verhaal. Als die onbekende bezoeker nog na zo'n 125 jaar met zekerheid de geleerde Leydis als schrijver

37 Kattendyke, cxlix.

38 Ibidem, cl.

39 Ibidem.

40 S. Bogaart, Geleerde kennis in de volkstaal. Van den proprieteyten der dinghen (Haarlem 1485) in perspectief (Hilversum, 2004) 160-163, 175. 
kon aanwijzen dan duidt dat in elk geval op een stevige traditie. Maar wat bedoelt hij met die ablatief auctore: met de auteur? Onder diens toezicht? Ik denk net als alle werkers aan onze editie dat Kattendyke niet van de hand of uit het brein van Leydis komt, alleen al om de praktische reden dat die in 1491 juist zo druk met andere kronieken bezig was. Maar wel bood de situatie in en om het Karmelieten-scriptorium hem de mogelijkheid om toe te kijken, en advies te geven, misschien te vertalen? Hij zat goed in de stof, en hij was een goed Latinist. Bovendien was hij, modern gezegd, communicatief: de geleerde abt Trithemius noemt hem 'buitengewoon goed in het preken in de volkstaal. ${ }^{, 41}$ Mogen we het onderschrift in Huyssens boek dan misschien lezen als 'uit de school van', 'uit het atelier', zoals kunsthistorici dat doen? Dat de naam Leydis nog opduikt na ruim een eeuw betekent misschien niet meer dan dat Huyssens geleerde gast nog altijd een Haarlems klokje hoorde luiden, en daar een redelijk bekende naam bij zocht.

Wij zetten onze zoektocht nog even voort. Intussen is er aanleiding genoeg om die te concentreren op Haarlem en 'omgeving Leydis'. En nu blijken ineens de genealogische krabbels van Johan Huyssen via de ontcijfering van Corrie Ridderikhoff een mogelijk verder spoor te bieden. Want het blijkt dat de laatste écht geleerde bezitter van de kroniek vóór hem, meester Pieter Hanneman, 'eerste griffier van Holland en de Bataafse zaken zeer toegenegen ${ }^{, 2}$, was getrouwd met een joffer Adriana van Kerckwerve (zij stierf in 1589 in Den Haag, hij aldaar in 1593). Hun enige volwassen-geworden dochter heet Adriana Hannemans, Vrouwe van Kerckwerve. ${ }^{43}$ Had moeder Adriana een 'Kerckwerve-kroniek' mee ten huwelijk gebracht, en wist haar geleerde echtgenoot Pieter Hanneman die op waarde te schatten? Is het dan niet heel toevallig dat de Haarlemse stadssecretaris Scheen Wissenzoon, de overschrijver van een aantal kronieken die ook door de Kattendyke-schrijver zijn gebruikt, ${ }^{44}$ zich 'van Kerckwerff' noemt? Behalve actief in de stadspolitiek was deze Scheen Wissenzoon dus ook sterk historisch geïnteresseerd. Wilde hij na al dat kopieerwerk nu eens zelf een kroniek samenstellen, en die ook uiterlijk goed verzorgen? En ligt het dan niet voor de hand dat hij steun zocht bij de expertise van een klooster-atelier in zijn eigen stad? En dat hij tenslotte, toen er geen drukker te vinden was, zijn kroniek maar aan zijn familie naliet?

Er is een reden vóór en een tegen deze identificatie. Ervóór pleit dat we in deze Scheen Wissenzoon van Kerckwerff de perfecte invulling vinden van het profiel van de nieuwe 'intellectueel' zoals die tegen het einde van de vijftiende eeuw een gezicht krijgt: de Nederlandse burger-humanist in opkomst, de stadssecretaris die zijn actuele beroep in een historische contekst probeert te vatten, zoals Peter van Os dit deed in Den Bosch, of Reinier Bogerman in Kampen. ${ }^{45}$ Deze secretarissen zijn goed in de omgang met pen en papier, ze

41 'declamator sermonum popularium praeclarus', aangehaald voorin de Leydis-editie van F. Sweertius (Francofurti 1620).

42 C. Ridderikhoff in Kattendyke, xxxii.

43 Aldaar, xliii (diplomatische uitgave van de eigenhandige notities van Johan Huyssen van Kattendyke op de schutbladen).

$44 \quad$ Zie hiervoor de noten 32 en 35. 
hebben een brede interesse, gebruiken het Latijn op een praktisch niveau, en zijn dus niet direct geleerd, maar wel beschaafd. Maar er pleit ook iets tegen dit voorstel, dat ik als buitenstaander hier wel kan ventileren, maar dat de experts van Kattendyke misschien wel op goede, handschriftelijke gronden naar de prullenmand hebben verwezen. Want onze Scheen Wissenzoon van Kerckwerff zou dus niet alleen Kattendyke hebben geschreven, maar ook al veel eerder al die andere kronieken hebben afgeschreven, en dat afschrift bestaat nog. ${ }^{46}$ Is dan één blik niet genoeg om te zien of hier dezelfde man aan het werk is geweest? Waarschijnlijk niet, want dan hadden we het vernomen. Mogelijk maakt het tijdsinterval van 25 jaar tussen beide schrijfsels én het feit dat er een schrijfhand naast een boekhand (de littera gotbica bybrida) staat de zaak toch lastig. Hoe dit zij, we krijgen het niet te horen. Sterker, de hele Scheen, die ooit al op andere gronden dan de Kerckwerve-connectie door Karin Tilmans zeer voorzichtig naar voren was geschoven ${ }^{47}$, verdwijnt stilaan uit het onderzoek. Anteun Janse noemt hem even in verband met de bronnen van de Kattendyke-auteur ${ }^{48}$, maar in het samenvattende opstel 'Karakteristiek van de auteur' van het driemanschap Van Anrooij, Biemans en Janse komt hij niet meer voor.

Dat voert tot een dubbele conclusie. Er ligt hier een prachtig boek waar de vaderlandse mediëvistiek bijzonder mee is gediend. Ik kan geen moderne Nederlandse kroniekuitgave bedenken waarmee in het universitaire onderwijs zoveel gedaan kan worden. Het makt ons precies duidelijk wat vijf eeuwen geleden onze vaderlandse canon was, hoe de mythische fundamenten werden gelegd, en hoe op het stramien van graven en bisschoppen het wereldkader 'regionaal' werd ingeperkt. Het is met bewonderenswaardige inzet en werkkracht tot stand gebracht. Maar de samenwerking van zoveel auteurs heeft soms een afvlakkende werking gehad, die ontstaat doordat men elkaar herhaalt ('de auteur was geen professional'), tegenspreekt ('Kattendyke is een wapenboek' versus 'Kattendyke is een kroniek') ${ }^{49}$ of tot nietszeggendheid drijft (de schrijver was 'een Hollander die uiteraard contact gehad kan hebben met een of meer Haarlemse ingezetenen'). ${ }^{50}$ De grote voorzichtigheid tegenover elkaar en het toekomstig publiek dreigt soms tot een wetenschappelijke hypercorrectheid te leiden die zijn eigen barrières opwerpt. Dan weet de belangstellende

45 Voor Van Os zie de inleiding in de uitgaven van zijn kroniek, hiervoor noot 5; voor Bogerman M. Carasso-Kok, Repertorium (hiervoor noot 26) xiii, 300, 353, 354. Onlangs heeft Janse zelf nog een kandidaat aan dit rijtje toegevoegd: de Utrechtse stadsklerk Jan Tolnaer voor de Nederlandse Beke ( \pm 1400$)$ : A. Janse, 'De Nederlandse Beke opnieuw bekeken’, Jaarboek voor Middeleeurese Geschiedenis, IX (2006) 116-149, hier 146.

46 Het al in noot 32 genoemde verzamelhandschrift.

47 'Zijn hand (in Kattendyke) is zeer verwant aan die van Scheen Wissenzoon de Kerckwerff en misschien mag aan hem of aan een van diens opvolgers uit de Haarlemse kanselarij gedacht worden ... Alleen archiefonderzoek kan uitwijzen op hij in 1491 nog actief was', Tilmans, 'De Kattendyke-kroniek', zie noot 2, 199 en noot 44.

48 Kattendyke, cxxv-cxxvi.

49 Ibidem, xvi.

50 Ibidem, cxlix. 
gebruiker niet meer welke zoekterm hij voor dit boek moet hanteren, of waar hij nog naar een auteur mag zoeken. Maar intussen leggen de verzamelde auteurs en speciaal de tekstbezorger zóveel op tafel dat ze anderen tot zoeken uitnodigen, en maken ze Kattendyke ook in dat opzicht een succes.

Bunna Ebels-Hoving (1932) was tot 1989 verbonden als docent Middeleeuwse geschiedenis aan het Instituut voor Geschiedenis van de RUG.

\section{Summary}

Bunna Ebels-Hoving, In search of the author of the 'Kattendyke Chronicle'

Dutch medieval history has always remained very much in the background and so have its chronicles. The latter are few and far between and rarely of high quality. The only really important ones are Melis Stoke's Rijmkroniek (ca. 1300) written in Middle Dutch and Johannes de Beke's Chronographia (ca. 1350 ) in Latin with its Middle Dutch anonymous sequels (the first one of which went as far as 1393). Works of comparable originality are absent for the $15^{\text {th }}$ century, when chroniclers mostly confined themselves to repeating both Stoke and Beke, their trusted authorities, and expanding on them, mostly succinctly, to reflect upon their own times. The majority of these manuscripts still have to be edited. What a surprise it was then when the newly-discovered 'Cronicke van Hollant, van Zeelant ende van Vrieslant ende van den Stichte van Utrecht' suddenly appeared after lying undisturbed for centuries in the possession of a Dutch aristocratic family who have now given permission for this beautifully illustrated manuscript to be edited by an interdisciplinary team of scholars. In some major respects the Kattendyke chronicle is disappointing: although written in 1492 it fails to add any substantial new information of either a factual or 'cultural' nature. But given the scarcity of well-edited medieval Dutch chronicles we should appreciate the Kattendyke chronicle as a product of intellectual history and as a serious undertaking of a so far unidentified Dutchman during the crucial years of expanding Burgundian rule. The editors have done a remarkable job but may have given up too readily on solving the mystery of the chronicler's identity, for which the present reviewer offers a suggestion. 
gebruiker niet meer welke zoekterm hij voor dit boek moet hanteren, of waar hij nog naar een auteur mag zoeken. Maar intussen leggen de verzamelde auteurs en speciaal de tekstbezorger zóveel op tafel dat ze anderen tot zoeken uitnodigen, en maken ze Kattendyke ook in dat opzicht een succes.

Bunna Ebels-Hoving (1932) was tot 1989 verbonden als docent Middeleeuwse geschiedenis aan het Instituut voor Geschiedenis van de RUG.

\section{Summary}

Bunna Ebels-Hoving, In search of the author of the 'Kattendyke Chronicle'

Dutch medieval history has always remained very much in the background and so have its chronicles. The latter are few and far between and rarely of high quality. The only really important ones are Melis Stoke's Rijmkroniek (ca. 1300) written in Middle Dutch and Johannes de Beke's Chronographia (ca. 1350 ) in Latin with its Middle Dutch anonymous sequels (the first one of which went as far as 1393). Works of comparable originality are absent for the $15^{\text {th }}$ century, when chroniclers mostly confined themselves to repeating both Stoke and Beke, their trusted authorities, and expanding on them, mostly succinctly, to reflect upon their own times. The majority of these manuscripts still have to be edited. What a surprise it was then when the newly-discovered 'Cronicke van Hollant, van Zeelant ende van Vrieslant ende van den Stichte van Utrecht' suddenly appeared after lying undisturbed for centuries in the possession of a Dutch aristocratic family who have now given permission for this beautifully illustrated manuscript to be edited by an interdisciplinary team of scholars. In some major respects the Kattendyke chronicle is disappointing: although written in 1492 it fails to add any substantial new information of either a factual or 'cultural' nature. But given the scarcity of well-edited medieval Dutch chronicles we should appreciate the Kattendyke chronicle as a product of intellectual history and as a serious undertaking of a so far unidentified Dutchman during the crucial years of expanding Burgundian rule. The editors have done a remarkable job but may have given up too readily on solving the mystery of the chronicler's identity, for which the present reviewer offers a suggestion. 


\title{
Grondslagen van verandering. Assimilatie en differentiatie van het Antwerpse boekbedrijf in de tweede helft van de zeventiende eeuw ${ }^{1}$
}

\author{
GERRIT VERHOEVEN
}

\section{Inleiding}

Uit economisch oogpunt was de late zeventiende en begin achttiende eeuw een bijzonder turbulente periode in de Zuid-Nederlandse geschiedenis. Vanaf de Vrede van Münster (1648) raakte het economische leven in Vlaanderen en Brabant immers steeds sterker ontwricht. ${ }^{2}$ Vooral de luxe-industrieën kregen rake klappen. De grote ateliers, waar men het fijnste textiel en weelderige wandtapijten weefde, oogverblindend diamant sleep, fraai ingelegde kunstkabinetten assembleerde of bijzonder aangrijpende barokke altaarstukken schilderde, sloten één voor één de deuren. Vanaf 1650 trokken steeds meer ondernemers hun kapitaal uit de slabakkende industrie en handel terug en belegden in veilige obligaties en renten. Werkeloosheid en stadsvlucht stegen tot ongeziene hoogten in Brabant. ${ }^{3}$ Aan de basis van de recessie lag een complexe reeks van in- en externe oorzaken. Uitermate ontregelend was de oorlog van Lodewijk XIV, die het beleg sloeg voor tal van Vlaamse steden en hun ommeland leegplunderde. Daardoor viel de koopkracht van de welvarende plattelandsbevolking al snel terug. Ook het agressieve mercantilisme waarmee Frankrijk en Engeland voortaan hun eigen markten afschermden, belemmerde de uitvoer van Zuid-Nederlandse luxeproducten. ${ }^{4}$

1 Gebruikte afkortingen: MPM = Museum Plantijn Moretus, $\mathrm{M}=$ Manuscripten, PA = Plantijns Archief; SAA = Stadsarchief Antwerpen, GA = Gilden en Ambachten; GF = Genealogisch Fonds, IB = Insolvente Boedelskamer, $\mathrm{N}=$ Notariaat, $\mathrm{R}=$ Rekenkamer; SABBE $=\mathrm{M}$. Sabbe, Briefwisseling van de gebroeders Verdussen 1669-1672 (2 dln.; Antwerpen, Den Haag, 1923). Met dank aan P. G. Hoftijzer, B. De Munck, B. Blondé, K. Bowen en I. Van Damme voor hun raadgevingen en kritiek.

2 Lees als inleiding: I. Van Damme, 'Het vertrek van Mercurius. Historiografische en hypothetische verkenningen van het economisch wedervaren van Antwerpen in de tweede helft van de zeventiende eeuw', NEHA-Jaarboek, LXVI (2003) 6-39.

3 A. K. L. Thijs, 'Structural changes in Antwerp industry from the fifteenth to the eighteenth century', in: H. Van der Wee, ed., The rise and decline of urban industries in Italy and in the Low Countries (Late Middle Ages - Early Modern Times) (Leuven, 1988) 207-212; A. K. L. Thijs, Van Geuzenstad tot katholiek bolwerk. Maatschappelijke betekenis van de kerk in contrareformatorisch Antwerpen (Turnhout, 1990) 56-57.

$4 \quad$ R. Baetens, De nazomer van Antwerpens welvaart. De diaspora en het handelshuis De Groote tijdens de eerste helft der $17^{\text {de }}$ eeuw (2 dln.; Brussel, 1976) I, 35; A. K. L. Thijs, 'De Antwerpse 